\title{
Improvement of Growth and Yield of Pea Plants Using Integrated Fertilization Management
}

\author{
Zaghloul R.A. ${ }^{1}$; H.E. Abou-Aly ${ }^{1}$, Rasha M. El-Meihy ${ }^{1}$, Mohamed.Talat. El-Saadony ${ }^{2, *}$ \\ ${ }^{1}$ Department of Agricultural Botany, Agricultural Microbiology Branch, Faculty of Agriculture, Benha University, Egypt \\ ${ }^{2}$ Department of Agricultural Microbiology, Faculty of Agriculture, Zagazig University, Egypt
}

Copyright $(\subset 2015$ by authors, all rights reserved. Authors agree that this article remains permanently open access under the terms of the Creative Commons Attribution License 4.0 International License

\begin{abstract}
Two field experiments were carried out during two successive winter seasons at 2013 and 2014, in a private farm at Abuo-Hammad area, Sharkia Governorate, Egypt, to evaluate the integrated fertilization management i.e. chemical fertilization (NPK), biofertilization (Rhizobium leguminosarum. bv. vicieae, Glomas bagyarajii, Bacillus circulans) with or without foliar applications of yeast extract (Saccharomyces cereviseae) and micronutrients on enzymes activity, nodulation status, growth characteristics, chemical constituents, mycorrhizal infection (\%) and yield of pea (Pisum sativum L.) cv. Master B grown under loamy sandy soil conditions. All estimated parameters were affected by biofertilizers application, especially in combination with foliar applied with yeast extract. The highest values of the most studied parameters were recorded in combination between biofertilizers with foliar application of micronutrients and yeast extract.
\end{abstract}

Keywords Pea, NPK, Biofertilization, Growth, Yeast Extract, Micronutrients, Yield

\section{Introduction}

Pea (Pisum sativum L.) is one of the most important leguminous vegetable crops grown during winter season in Egypt for local consumption and exportation. The pods of pea contain a great amount of protein and carbohydrates. So that pea is considered as one of the most important sources in human nutrition. Fertilizers come in two types; they are either chemical or biofertilizers. Chemical fertilizers play an important role on plant growth and productivity. Nitrogen is essential for synthesis of chlorophyll, enzymes and protein. Phosphorus is essential for root growth, phospho-proteins, phospholipids and ATP, ADP formation. Potassium plays an important role in the promotion of enzyme activity and enhancing the translocation of assimilates and protein synthesis [15].

Increasingly high inputs of these chemical fertilizers during the last 150 years have not only left soils degraded, polluted and less productive but have also posed severe health and environmental hazards. Organic farming methods (such as the use of biofertilizers) would solve these issues and make the ecosystem healthier. Biofertilizers play a very important role in improving soil fertility by fixing atmospheric nitrogen both in association with plant roots and without it, solubilize insoluble soil phosphates and produces plant growth substances in the soil [36]. The inoculation of legume seed crops with associative $\mathrm{N}_{2}$-fixing bacteria led to change and improve plant growth and yield [33]. In addition, Badr et al., [6] indicated that inoculated plants significantly surpassed un-inoculated ones in number of nodules/plant, plant height, number of branches and pods/plant, seed yield/plant, 100-seed weight and seed yield/fed. On the other hand, the number of seed/pod, pods weight/plant, seed $\mathrm{N}$ content $\%$ and seed protein content $\%$ were not affected by inoculation.

Many studies have indicated that yeast is one of the richest sources of high quality protein, especially the essential amino acids, the essential minerals and trace elements such as $\mathrm{Ca}, \mathrm{Co}, \mathrm{Fe}$. Also, yeast extract is the best source of the B-complex vitamins, amino acids furthermore, bio-constituents especially, cytokinins [19]. Also, yeast extracts improved all vegetative growth parameters, flowering, total yield and pods quality of pea plants. In respect of using micronutrients Sarkar et al. [26] showed that a small amount of nutrients, particularly $\mathrm{Zn}, \mathrm{Fe}$ and $\mathrm{Mn}$ applied by foliar spraying were significantly increased the yield of crops. $\mathrm{Zn}$ is known to have an important role either as a metal component of enzymes or as a cofactor of a large number of enzymes [12]. Where, Fe plays essential roles in the photosynthesis [32]. Also, Andrzejewska [4] reported that the increase of seed yield affected by microelement fertilization resulted from the increase in the number of pods/plant and to a lower extent of the increase in the number of seeds per pod.

This study aimed to evaluate the integrated fertilization management used in the current study for enhancement growth performance, chemical constituents and yield of pea 
(Pisum sativum L.) cv. Master B has grown under loamy sandy soil conditions.

\section{Materials and Methods}

Two field experiments were carried out during two successive winter seasons 2013 and 2014, in a private farm at Abuo-Hammad area, Sharkia Governorate, Egypt, under loamy sandy soil conditions.

Experimental soil was subjected to mechanical and chemical analyses according to the method described by Page et al. [24]. Soil texture and chemical analyses are presented in Table (1).

Table 1. Mechanical and chemical analyses of the experimental soil.

\begin{tabular}{|c|c|c|c|}
\hline \multirow{2}{*}{ Parameters } & \multirow{2}{*}{ Unit } & \multicolumn{2}{|r|}{ Value } \\
\hline & & $1^{\text {st }} 2013$ & $2^{\text {nd }} 2014$ \\
\hline \multicolumn{4}{|c|}{ Mechanical analyses } \\
\hline Sand & & 76.8 & 76.8 \\
\hline Silt & $\%$ & 13.41 & 13.41 \\
\hline Clay & & 9.79 & 9.79 \\
\hline Textural class & & $\begin{array}{c}\text { Loamy } \\
\text { sand }\end{array}$ & Loamy sand \\
\hline \multicolumn{4}{|c|}{ Chemical analysis } \\
\hline Field capacity (FC) & & 10.23 & 10.23 \\
\hline Organic matter, & $\%$ & 0.68 & 0.69 \\
\hline $\mathrm{pH}^{*}$ & & 8.02 & 8.02 \\
\hline $\mathrm{EC}^{* *}$ & $\mathrm{dSm}$ & 0.34 & 0.34 \\
\hline \multicolumn{4}{|l|}{ Soluble cations ${ }^{* *}$} \\
\hline $\mathrm{Ca}^{++}$ & \multirow{4}{*}{ mmolc $\mathrm{L}^{-1}$} & 0.70 & 0.70 \\
\hline $\mathrm{Mg}^{++}$ & & 0.84 & 0.83 \\
\hline $\mathrm{Na}^{+}$ & & 1.64 & 1.65 \\
\hline $\mathrm{K}^{+}$ & & 0.18 & 0.18 \\
\hline \multicolumn{4}{|l|}{ Soluble anions } \\
\hline $\mathrm{CO}_{3}=$ & \multirow{4}{*}{ mmolc L $\mathrm{L}^{-1}$} & - & - \\
\hline $\mathrm{HCO}_{3}^{-}$ & & 0.40 & 0.40 \\
\hline $\mathrm{Cl}^{-}$ & & 1.49 & 1.50 \\
\hline $\mathrm{SO}_{4}=$ & & 1.47 & 1.46 \\
\hline \multicolumn{4}{|l|}{ Available nutrients } \\
\hline $\mathrm{N}$ & & 82.9 & 83.9 \\
\hline $\mathrm{P}$ & mg kg-1soil & 11.5 & 14.5 \\
\hline $\mathrm{K}$ & & 113 & 116 \\
\hline
\end{tabular}

\subsection{Experimental Design}

Treatments were distributed in a split-split plot design with three replicates. NPK treatments and biofertilization addition were assigned at random in the main plots, while sub plots were devoted to foliar applications micronutrients and Saccharomyces extract which were allotted in sub-sub plots.

- Chemical fertilizers (NPK) were used as recommended full dose $100 \% \mathrm{NPK}$ (40 $\mathrm{kg} \mathrm{N}_{2}$ as ammonium sulfate, $30 \quad \mathrm{~kg} \quad \mathrm{P}_{2} \mathrm{O}_{5}$ as calcium superphosphate and $50 \mathrm{~kg} \mathrm{~K}_{2} \mathrm{O}$ as potassium sulfate).

- Biofertilizers contain three bacterial strains namely Rhizobium leguminosarum bv. vicieae, Glomas bagyarajii and Bacillus circulans.

- Yeast extract (Saccharomyces cereviseae) was applied at a rate of $3 \mathrm{~L} /$ fed.

- Micronutrients solution which contains 5.1\% N, 6\% $\mathrm{Fe}, 0.5 \% \mathrm{Zn}, 0.5 \% \mathrm{Mn}, 0.5 \% \mathrm{Cu}, 0.0005 \% \mathrm{Mo}, 4 \% \mathrm{~S}$, $0.0 .02 \% \mathrm{~B}$ and $10 \%$ citric acid was obtained from Sphinx for International Trade Company, Cairo, Egypt was prepared at a rate of $(2 \mathrm{ml} / \mathrm{L})$ and then used as foliar spray at a rate of $3 \mathrm{~L} / \mathrm{fed}$.

\subsection{Experimental Treatments}

Flow chart of experimental treatments

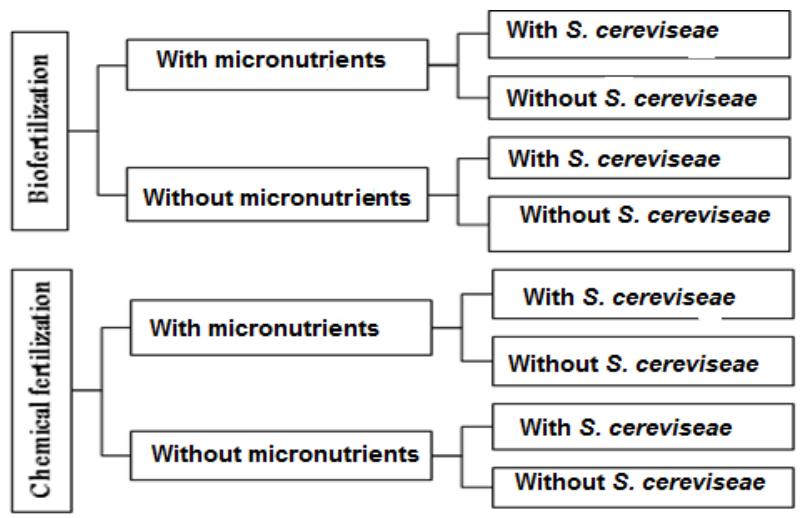

\subsection{Preparation of Biofertilizers Inocula}

The biofertilizers inocula for pea plants were prepared in specific broth media. $R$. leguminosarum bv. viciae was grown in yeast extract mannitol (YEM) broth [30] for seven days, bacterial inoculum was estimated using a plate dilution method [34]. B. circulans was grown on tryptic soy broth (TSB) with $10 \%$ sodium chloride [16] for two days. Arbuscular mycorrhiza fungi (G. bagyarajii) was obtained from biofertilization unit, Fac. Agric. Ain Shams Univ., Egypt.

\subsection{Preparation of Saccharomyces cerevisiae Extract}

Local isolate of $S$. cerevisiae was obtained from biofertilization unit, Fac. Agric. Ain Shams Univ., Egypt. Saccharomyces extract was prepared using a technique described by Abd EI-Rahim et al. [3]. Chemical analyses of Saccharomyces extract stock solution are presented in Table (2). 
Table 2. Analysis of Saccharomyces extract stock solution.

\begin{tabular}{lc|cc|cc}
\hline & Value & $\begin{array}{c}\text { Macro- } \\
\text { elements } \\
(\%)\end{array}$ & Value & $\begin{array}{c}\text { Micro- } \\
\text { elements } \\
(\mathrm{ppm})\end{array}$ & Value \\
\hline $\begin{array}{c}\text { Total } \\
\text { protein (\%) } \\
\begin{array}{c}\text { Total-carb } \\
\text { ohydrates } \\
(\%)\end{array}\end{array}$ & 5.3 & $\mathrm{~N}$ & 1.2 & $\mathrm{Fe}$ & 0.13 \\
$\begin{array}{c}\text { IAA } \\
(\mu \mathrm{g} / \mathrm{ml})\end{array}$ & 0.5 & $\mathrm{Mg}$ & 0.13 & $\mathrm{Mn}$ & 0.07 \\
$\begin{array}{c}\mathrm{GA} \mathrm{A}_{3} \\
(\mu \mathrm{g} / \mathrm{ml})\end{array}$ & 0.3 & $\mathrm{Ca}$ & 0.02 & $\mathrm{Zn}$ & 0.04 \\
\hline
\end{tabular}

IAA (Indol Acetic Acid) $\quad \mathrm{GA}_{3}$ (Gibberellic Acid)

\subsection{Cultivation Process}

The experimental plot area was $10.5 \mathrm{~m}^{2}$ and included 5 rows (each was $3.5 \mathrm{~m}$ length and $60 \mathrm{~cm}$ width) and the distance between plants was $15 \mathrm{~cm}$. The normal cultural practices, i.e. irrigation, fertilizer and pest control for the pea production were followed. Prior cultivation, seeds of pea (Pisum sativum L.) Master B. were obtained from the Agronomy Res. Inst. ARC, Giza, Egypt. Before sowing, seeds were surface sterilized with acidified $0.01 \% \mathrm{HgCl}_{2}$ for 5 minutes and after serial washings with sterilized water, they were inoculated by soaking for one hour in the prepared inocula namely $R$. leguminosarum bv. viciae ( $1 \mathrm{ml}$ contains about $\left.10^{9} \mathrm{cfu}\right)$, B. circulans $\left(1 \mathrm{ml}\right.$ contains about $\left.40 \times 10^{6} \mathrm{cfu}\right)$ and G. bagyarajii at range of $95-100$ spores $/ \mathrm{ml}$. An amount of Arabic Gum (20\%) was added as adhering agent then, spread in plates and allowed to air drying before sowing. The control seeds were soaked by the same manner, but in the corresponding media without inocula.

\subsection{Determinations}

\subsubsection{Enzymes activity}

Phosphatase activity was estimated in the rhizospheric soil of pea plants according to Drobrikova [8] and phosphorus in filtrate was determined colorimetrically according to the method described by A.P.H.A. [2] as $\mu \mathrm{g} \mathrm{P} / \mathrm{g}$ dry soil. Nitrogenase activity was estimated in nodules using an acetylene reduction technique according to Silvester [28] as $\mu \mathrm{C}_{2} \mathrm{H}_{4} / \mathrm{g}$ dry nodules.

\subsubsection{Nodulation Status}

Six plants from each plot were taken at random after 50 days from sowing to evaluate the number of nodules/plant, fresh and dry weight of nodules (g).

\subsubsection{Determination of AM infection percentage}

$\mathrm{KOH}$ solution for 30 minutes, washed with water and then HCL $20 \%$, was added. Root samples were placed in lactophenol solution for 4 min. After washing, counterstaining was performed by boiling in lactic trypan blue for $10 \mathrm{~min}$. [22] The formation of AM was assessed in 50 root segments for each sample using the microscopic examination at $100 \mathrm{x}$ magnification.

\subsubsection{Growth characteristics and soil macro-elements content}

Six plants from each plot were taken at random after 45 days from sowing to evaluate plant height $(\mathrm{cm})$, number of branches/plant, dry weight of stem $(\mathrm{g})$, dry weight of pods (g). Macro-elements content in the soil (total nitrogen, phosphorus and potassium) were estimated according to the methods described by A.O.A.C., [1]; A.P.H.A., [2] and Dewis and Freitas, [7], respectively.

\subsubsection{Seed analysis}

Six plants from each plot were taken at random after 120 days from sowing, mature green pods were continuously harvested in suitable maturity stages and then estimate the seed minerals contents (NPK \%) and Total crude protein (\%) according to A.O.A.C., [1]; A.P.H.A., [2] and Dewis and Freitas, [7], total carbohydrate was determined colorimetrically using the method described by Dubois et al. [9].

\subsubsection{Yield and its components}

Six plants from each plot were taken at random after 130 days from sowing to evaluate a number of pods/plant, number of seeds/pod, average weight of 100 seeds (g), dry weight of seed/pods (g) and total green pods yield per feddan (ton/fed.).

\subsection{Statistical Analysis}

Statistical analysis was carried out according to Snedecor and Cochran [29]. The differences between the mean values of various treatments were compared by Duncan's multiple range test Duncan's, [10].

\section{Results and Discussion}

\subsection{Effect of Integrated Fertilization Management on Microbial Enzymes Activity}

Data in Table (3) show the $\mathrm{N}_{2}$-ase activity in nodules was affected by all investigated treatments. It was clearly that pea plants treated only with chemical fertilizers gave lower values of $\mathrm{N}_{2}$-ase activity than plants treated with biofertilizers. This result is in harmony with that obtained from Anne-Sophie et al. [5] who demonstrated that the addition of chemical fertilizers decreased nitrogenase

Fresh root samples were washed with water, boiled in a $10 \%$ activity. 
Table 3. Effect of integrated fertilization management on microbial enzymes activities.

\begin{tabular}{|c|c|c|c|c|c|c|}
\hline \multirow[b]{3}{*}{ Fertilization } & \multicolumn{2}{|l|}{ Treatments } & \multicolumn{2}{|c|}{$\begin{array}{c}\text { Nitrogenase activity } \\
\text { as } \mu \mathrm{l} \mathrm{C}_{2} \mathrm{H}_{4} / \mathrm{g} \text { dry nodules }\end{array}$} & \multicolumn{2}{|c|}{$\begin{array}{c}\text { Phosphatase activity as } \mu \mathrm{g} \\
\text { P/g dry soil }\end{array}$} \\
\hline & \multicolumn{2}{|c|}{ Foliar application } & \multirow[b]{2}{*}{$1^{\mathrm{st}}$} & \multirow[b]{2}{*}{$2^{\text {nd }}$} & \multirow[b]{2}{*}{$1^{\mathrm{st}}$} & \multirow[b]{2}{*}{$2^{\text {nd }}$} \\
\hline & Microelements & $\begin{array}{c}\text { Saccharomyces } \\
\text { extract }\end{array}$ & & & & \\
\hline \multirow{4}{*}{ Chemical } & \multirow[t]{2}{*}{ Without } & - & $23.00^{\mathrm{e}^{*}}$ & $34.33^{\mathrm{g}}$ & $13.00^{\mathrm{e}}$ & $12.67^{\mathrm{e}}$ \\
\hline & & + & $32.00^{\mathrm{d}}$ & $50.00^{d}$ & $15.00^{\mathrm{d}}$ & $18.33^{\mathrm{c}}$ \\
\hline & \multirow[t]{2}{*}{ With } & - & $24.33^{\mathrm{e}}$ & $41.00^{f}$ & $13.33^{\mathrm{e}}$ & $15.33^{\mathrm{d}}$ \\
\hline & & + & $33.67^{\mathrm{d}}$ & $46.00^{\mathrm{e}}$ & $15.67^{\mathrm{d}}$ & $16.67^{\mathrm{d}}$ \\
\hline \multirow{4}{*}{ Biofertilization } & \multirow[t]{2}{*}{ Without } & - & $62.00^{\mathrm{c}}$ & $76.67^{\mathrm{c}}$ & $34.33^{b}$ & $35.33^{\mathrm{b}}$ \\
\hline & & + & $71.67^{\mathrm{b}}$ & $84.00^{\mathrm{b}}$ & $36.67^{\mathrm{a}}$ & $40.33^{\mathrm{a}}$ \\
\hline & \multirow[t]{2}{*}{ With } & - & $71.67^{\mathrm{b}}$ & $86.67^{a b}$ & $31.67^{\mathrm{c}}$ & $34.67^{\mathrm{b}}$ \\
\hline & & + & $87.67^{\mathrm{a}}$ & $90.00^{\mathrm{a}}$ & $37.33^{\mathrm{a}}$ & $40.33^{\mathrm{a}}$ \\
\hline
\end{tabular}

*Values having the same alphabetical letter(s) did not significantly differ at the $\mathrm{p}>0.05$ level of significance, according to Duncan's multiple range test.

The highest significant values of $\mathrm{N}_{2}$-ase activity were observed in nodules formed in plants inoculated with biofertilizers in combination with micronutrients and Saccharomyces extract. This result may be due to the activities of inocula in addition to the synergistic effect between inocula and extract of $S$. cerevisiae. These results are in harmony with Mishra et al. [20] who found that pea plant inoculated with $R$. leguminosarum and Glomus spp. gave a significant increase in $\mathrm{N}_{2}$-ase activity. It could be recommended that application of natural biostimulants especially yeast extract led to overcome the deleterious effect of drought and consequently resulted in improved the productivity of wheat and its grain quality (Physiological and biochemical studies on drought tolerance of wheat plants by application of amino acids and yeast extract. Also, Hammad [14] reported that foliar spraying of pea plant with yeast extract improved enzyme activities. In this respect, Shumin et al. [27] proved that mycorrhizal colonization with $G$. mosseae combined with $R$. leguminosarum increased the enzyme activities of pea plants.

Concerning the effect of pea inoculation with integrated fertilization management on phosphatase activity, results registered in Table (3) emphasized that the lowest values of phosphatase activity were observed in soil with chemical fertilizers only. This trend of results was observed in two seasons. Soil inoculated with biofertilizers combined with Saccharomyces extract in the presence of micronutrients gave the highest significant values of phosphatase activity. This result may be attributed not only to the effect of inoculation on microbe's number in rhizosphere but also to the beneficial effect of yeast extract on indigenous and the introduced microbial strains for their proliferation and their activities. These results are in agreement with Shumin et al. [27] who found that the inoculation of plants with both $G$. mosseae and $R$. leguminosarum increase the acid and alkaline phosphatase activities compared with the control.

\subsection{Effect of Integrated Fertilization Management on Pea Nodules Characters}

Data in Table (4) show the effect of integrated fertilization management on nodules characters in root of pea plants during the two winter seasons. In this respect, data indicated that all nodules parameters, i.e. nods number/plant and nod fresh and dry weight were lower in plants fertilized with chemical fertilizers than plants inoculated with biofertilizers either in the presence or absence of foliar application. The highest values of all nodules characters were observed in the case of plants inoculated with biofertilizers in combination with foliar application with micronutrients and yeast extract. This trend of results was observed in the two seasons. These results are in harmony with Subba Rao [31] who found that co-inoculation of pea plants with $R$. leguminosarum and Glomus sp. result in significant increase in nodule number, nodule fresh weight. Also, Loguerre [18] reported that the inoculation of garden pea with rhizobia increased nodule numbers and weights and nodule dry matter.

On the other hand, the data clearly indicated that no significant differences in nodules dry weight in all chemical fertilization treatments during the two growing seasons. 
Table 4. Effect of integrated fertilization management on nodules characters in root of pea plants.

\begin{tabular}{|c|c|c|c|c|c|c|c|c|}
\hline \multirow{3}{*}{ Fertilization } & \multicolumn{2}{|l|}{ Treatments } & \multicolumn{2}{|c|}{ Nod number/ plant } & \multicolumn{2}{|c|}{ Nod FW } & \multicolumn{2}{|c|}{ Nod DW } \\
\hline & \multicolumn{2}{|c|}{ Foliar application } & \multirow[b]{2}{*}{$1^{\text {st }}$} & \multirow[b]{2}{*}{$2^{\text {nd }}$} & \multirow[b]{2}{*}{$1^{\text {st }}$} & \multirow[b]{2}{*}{$2^{\text {nd }}$} & \multirow[b]{2}{*}{$1^{\text {st }}$} & \multirow[b]{2}{*}{$2^{\text {nd }}$} \\
\hline & Microelements & S. cerevisiae & & & & & & \\
\hline \multirow{4}{*}{ Chemical } & \multirow[t]{2}{*}{ Without } & - & $4.0^{\mathrm{e} *}$ & $1.6^{\mathrm{e}}$ & $0.040^{\mathrm{f}}$ & $0.030^{\mathrm{g}}$ & $0.001^{\mathrm{d}}$ & $0.001^{\mathrm{d}}$ \\
\hline & & + & $5.0^{\mathrm{d}}$ & $5.3^{\mathrm{c}}$ & $0.056^{\text {ef }}$ & $0.171^{\mathrm{e}}$ & $0.003^{d}$ & $0.001^{\mathrm{d}}$ \\
\hline & \multirow[t]{2}{*}{ With } & - & $3.3^{\mathrm{e}}$ & $1.3^{\mathrm{e}}$ & $0.043^{\mathrm{f}}$ & $0.054^{\mathrm{g}}$ & $0.001^{\mathrm{d}}$ & $0.001^{\mathrm{d}}$ \\
\hline & & + & $5.0^{\mathrm{d}}$ & $3.0^{\mathrm{d}}$ & $0.070^{\mathrm{e}}$ & $0.097^{\mathrm{f}}$ & $0.003^{\mathrm{d}}$ & $0.003^{\mathrm{d}}$ \\
\hline \multirow{4}{*}{ Biofertilization } & \multirow[t]{2}{*}{ Without } & - & $12.3^{\mathrm{c}}$ & $14.3^{\mathrm{b}}$ & $0.333^{\mathrm{d}}$ & $0.343^{\mathrm{c}}$ & $0.033^{\mathrm{c}}$ & $0.027^{\circ}$ \\
\hline & & + & $15.6^{\mathrm{b}}$ & $22.0^{\mathrm{a}}$ & $0.433^{\mathrm{b}}$ & $0.420^{\mathrm{b}}$ & $0.043^{\mathrm{b}}$ & $0.037^{\mathrm{b}}$ \\
\hline & \multirow[t]{2}{*}{ With } & - & $12.0^{\mathrm{c}}$ & $14.6^{\mathrm{b}}$ & $0.400^{\mathrm{c}}$ & $0.276^{\mathrm{d}}$ & $0.040^{\mathrm{b}}$ & $0.045^{\mathrm{a}}$ \\
\hline & & + & $18.3^{\mathrm{a}}$ & $21.3^{\mathrm{a}}$ & $0.566^{\mathrm{a}}$ & $0.478^{\mathrm{a}}$ & $0.056^{\mathrm{a}}$ & $0.047^{\mathrm{a}}$ \\
\hline
\end{tabular}

*Values having the same alphabetical letter(s) did not significantly differ at the $\mathrm{p}>0.05$ level of significance, according to Duncan's multiple range test.

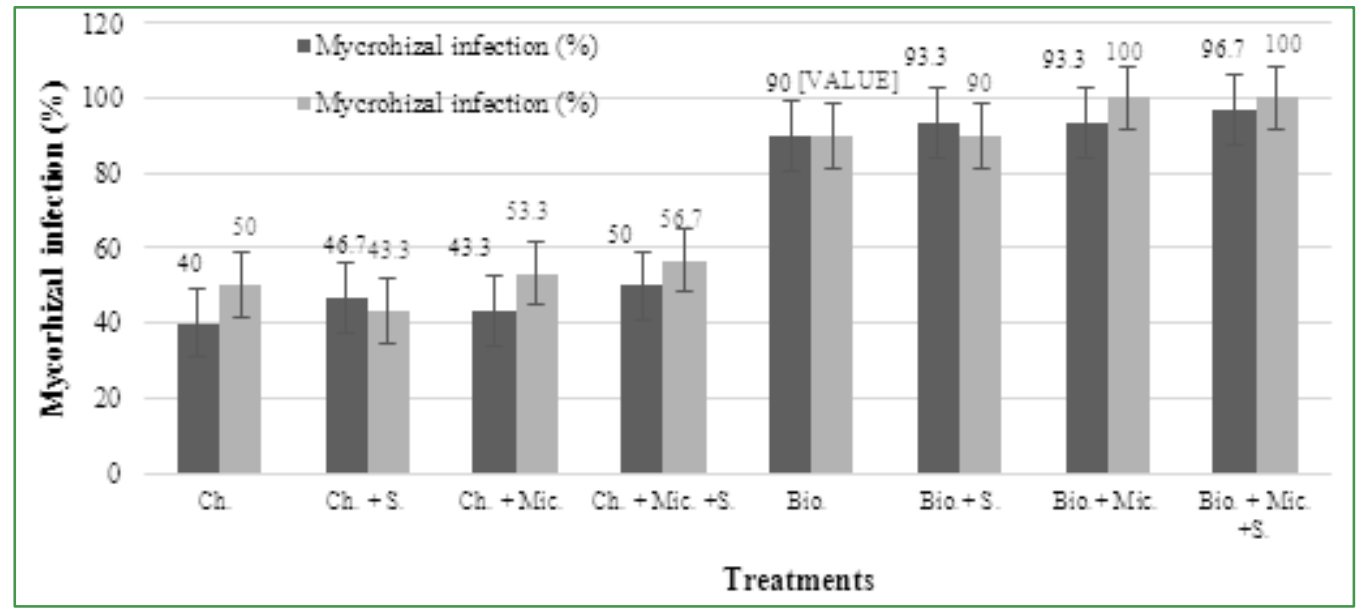

Figure 1. AM infection percentage in pea roots of mycorrhizal spores in soil extend from the first season to the second

\subsection{Effect of Integrated Fertilization Management on AM Infection Percentage}

Mycrohizal infection percentage in pea roots was estimated during the two seasons. Data illustrated by Fig.1 show the mycorrhizal infection (\%) in the second season was greater than the first season. These results are logic because the survival of mycorrhizal spores in soil extends from the first season to the second.

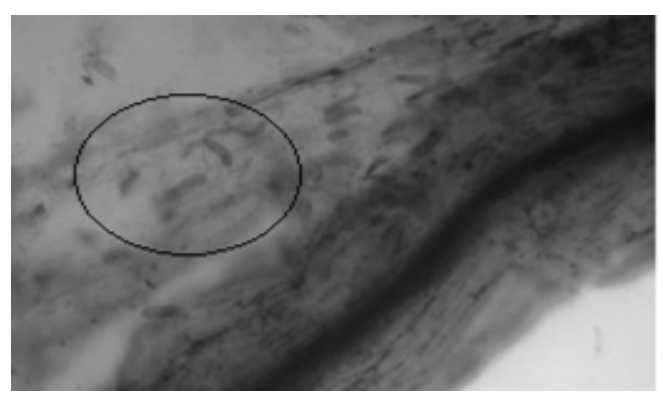

Figure 2a. Vesicles of AM inside pea roots

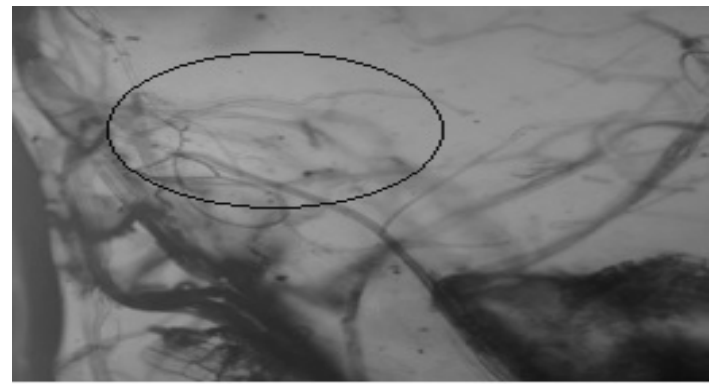

Figure 2b. AM hypha on pea roots

In addition, plants inoculated with biofertilizers in combination with micronutrients either in the presence or absence of yeast extract gave the same mycorrhizal infection $(100 \%)$ in the 2nd season, also, plants treated with biofertilizers only or combined with yeast extract gave the same mycorrhizal infection $(90 \%)$ in the second season. These results clearly indicated that yeast extract has no effect on mycorrhizal infection (\%). 
Table 5. Effect of integrated fertilization management on pea growth performance.

\begin{tabular}{|c|c|c|c|c|c|c|c|c|c|c|}
\hline \multicolumn{3}{|c|}{ Treatments } & \multicolumn{2}{|c|}{$\begin{array}{l}\text { Plant height } \\
(\mathrm{cm})\end{array}$} & \multicolumn{2}{|c|}{$\begin{array}{c}\text { Number of } \\
\text { branch/plant }\end{array}$} & \multicolumn{2}{|c|}{$\begin{array}{l}\text { Dry weight of stem } \\
(\mathrm{g})\end{array}$} & \multicolumn{2}{|c|}{$\begin{array}{l}\text { Dry weight of pods } \\
\text { (g) }\end{array}$} \\
\hline \multirow[b]{2}{*}{ Fertilization } & \multicolumn{2}{|c|}{ Foliar application } & \multirow[b]{2}{*}{$1^{\mathrm{st}}$} & \multirow[b]{2}{*}{$2^{\text {nd }}$} & \multirow[b]{2}{*}{$1^{\mathrm{st}}$} & \multirow[b]{2}{*}{$2^{\text {nd }}$} & \multirow[b]{2}{*}{$1^{\mathrm{st}}$} & \multirow[b]{2}{*}{$2^{\text {nd }}$} & \multirow[b]{2}{*}{$1^{\mathrm{st}}$} & \multirow[b]{2}{*}{$2^{\text {nd }}$} \\
\hline & $\begin{array}{l}\text { Microelemen } \\
\text { ts }\end{array}$ & S. cerevisiae & & & & & & & & \\
\hline \multirow{4}{*}{ Chemical } & \multirow{2}{*}{ Without } & - & $51.00^{\mathrm{e} *}$ & $49.00^{\mathrm{d}}$ & $3.66^{\mathrm{d}}$ & $3.66^{\mathrm{d}}$ & $0.79^{\mathrm{c}}$ & $0.70^{\mathrm{e}}$ & $13.67^{\mathrm{e}}$ & $12.33^{\mathrm{g}}$ \\
\hline & & + & $59.67^{\mathrm{c}}$ & $60.33^{\mathrm{b}}$ & $5.33^{\mathrm{ab}}$ & $4.00^{\mathrm{cd}}$ & $0.87^{\mathrm{c}}$ & $0.72^{\mathrm{e}}$ & $22.67^{\mathrm{c}}$ & $24.33^{\mathrm{b}}$ \\
\hline & \multirow{2}{*}{ With } & - & $60.00^{\mathrm{c}}$ & $51.67^{\mathrm{c}}$ & $4.00^{\mathrm{d}}$ & $3.00^{\mathrm{e}}$ & $0.89^{\mathrm{c}}$ & $0.92^{\mathrm{d}}$ & $17.33^{\mathrm{d}}$ & $18.67^{\mathrm{e}}$ \\
\hline & & + & $68.00^{\mathrm{b}}$ & $59.00^{\mathrm{b}}$ & $5.00^{\mathrm{bc}}$ & $3.66^{\mathrm{d}}$ & $1.36^{\mathrm{b}}$ & $1.62^{\mathrm{b}}$ & $23.00^{\mathrm{c}}$ & $22.67^{\mathrm{c}}$ \\
\hline \multirow{4}{*}{ Biofertilization } & \multirow{2}{*}{ Without } & - & $51.33^{\mathrm{e}}$ & $52.67^{\mathrm{c}}$ & $4.66^{\mathrm{c}}$ & $3.66^{\mathrm{d}}$ & $0.88^{\mathrm{c}}$ & $0.94^{\mathrm{d}}$ & $23.00^{\mathrm{c}}$ & $21.33^{\mathrm{d}}$ \\
\hline & & + & $75.00^{\mathrm{a}}$ & $63.33^{\mathrm{a}}$ & $5.66^{\mathrm{a}}$ & $4.66^{\mathrm{b}}$ & $1.36^{\mathrm{b}}$ & $1.23^{\mathrm{c}}$ & $29.33^{\mathrm{b}}$ & $28.00^{\mathrm{a}}$ \\
\hline & \multirow{2}{*}{ With } & - & $55.67^{\mathrm{d}}$ & $59.00^{\mathrm{b}}$ & $4.00^{\mathrm{d}}$ & $4.33^{\mathrm{bc}}$ & $1.51^{\mathrm{ab}}$ & $1.65^{\mathrm{b}}$ & $23.67^{\mathrm{c}}$ & $15.67^{\mathrm{f}}$ \\
\hline & & + & $74.00^{\mathrm{a}}$ & $64.00^{\mathrm{a}}$ & $5.66^{\mathrm{a}}$ & $5.67^{\mathrm{a}}$ & $1.66^{\mathrm{a}}$ & $2.03^{\mathrm{a}}$ & $32.33^{\mathrm{a}}$ & $28.67^{\mathrm{a}}$ \\
\hline
\end{tabular}

*Values having the same alphabetical letter(s) did not significantly differ at the $\mathrm{p}>0.05$ level of significance, according to Duncan's multiple range test.

\subsection{Effect of Integrated Fertilization Management on Pea Growth Performance}

Data in Table (5) clearly indicated that the lowest records of pea growth characteristics, i.e. plant height, number of branches per plant, dry weight of stem and dry weight of pods were observed in plants cultivated in soil without any amendments.

Also, data showed that the effect of either NPK or biofertilizers in combination with two foliar application, micronutriens and yeast extract, effect on pea growth performance during the two seasons.

Concerning the effect of chemical fertilization, data in Table (5) shows that no significant increase was observed in plant height in soil treated with either chemical fertilizers or biofertilizers only. Generally, plants inoculated with biofertilizers in combination with foliar application of Saccharomyces extract or micronutrients gave higher values of all estimated parameters than plants fertilized with chemical fertilizers in the presence or absence of foliar application.

Data also revealed that the highest significant values of all estimated parameters were observed in case of pea inoculated with biofertilizers combined with yeast extract in presence of micronutrients. This may be due to the beneficial effect of introduced inocula and also the important of micronutrients on plant growth. These results are in agreement with Sarkar et al. [26] who found that micronutrients, particularly $\mathrm{Zn}, \mathrm{Fe}$ and $\mathrm{Mn}$ applied by foliar spraying were significantly increased the vegetative growth. In addition, pea growth parameters were affected by yeast extract spraying because yeast extract was the best source of plant promotor hormones which enhance plant growth. In this respect, Zaki et al. [37] found that the beneficial effect of yeast on crop growth characters was an increase in all growth characters if compared with its control. The positive effect of yeast extract may be due to the fact that it is a natural source of phytohormones, vitamins and most essential elements.

\subsection{Effect of Integrated Fertilization Management on N, $P$ and $K$ in Soil}

Macro-nutrient elements (nitrogen, phosphorus and potassium) content were estimated in soil inoculated with different treatments. In this respect, data in Table (6) show that $\mathrm{N}$ and $\mathrm{P}$ content in soil increased during the second season than the first one in soil cultivated with plants fertilized with biofertilizers in combination with foliar application with Saccharomyces extract and micronutrients.

The lowest records of total nitrogen, phosphorus and potassium were observed in soil treated with chemical fertilizers without any foliar applications with either Saccharomyces extract or micronutrients. Whereas, the highest records were observed in plants inoculated with biofertilizers in combination with the two foliar applications, this may be due to the synergistic effect between rhizobia and AM fungi. This trend of results has been confirmed by Shumin et al. [27] who reported that phosphorus and nitrogen uptake of legumes was enhanced by inoculating with arbuscular mycorrhizal fungus and rhizobia.

Also, El-Kramany et al. [11] found that fixation of $\mathrm{N}_{2}$ bacteria presses the ability to bring insoluble $\mathrm{N}$ in soluble forms secreting organic acid such as formic acetic and lactic acids. Such acid lowers the $\mathrm{pH}$ and bring about the dissolution of bonds forms of $\mathrm{N}$ and render them available for growing plants. In addition, Xiurong et al. [35] reported that AM fungi significantly reduced the negative effect of $\mathrm{P}$ deficiency. Also, significant correlation between growth and nodulation proves a synergistic effect between rhizobia and AM fungi on legumes and this effect is dependent upon nutrient status. 
Table 6. Effect of integrated fertilization management on N, P and $\mathrm{K}$ in soil.

\begin{tabular}{|c|c|c|c|c|c|c|c|c|}
\hline \multicolumn{3}{|c|}{ Treatments } & \multicolumn{2}{|c|}{$\mathrm{N}$} & \multicolumn{2}{|c|}{$\mathrm{P}$} & \multicolumn{2}{|c|}{ K } \\
\hline \multirow{2}{*}{ Fertilization } & \multicolumn{2}{|c|}{ Foliar application } & \multicolumn{6}{|c|}{$(\mathrm{ppm})$} \\
\hline & Microelements & S. cerevisiae & $1^{\text {st }}$ & $2^{\text {nd }}$ & $1^{\text {st }}$ & $2^{\text {nd }}$ & $1^{\text {st }}$ & $2^{\text {nd }}$ \\
\hline \multirow{5}{*}{ Chemical } & Without & - & $81.00^{\mathrm{e}^{*}}$ & $75.33^{\mathrm{g}}$ & $14.33^{\mathrm{c}}$ & $13.00^{\mathrm{f}}$ & $109.0^{\mathrm{f}}$ & $103.3^{\mathrm{f}}$ \\
\hline & & + & $88.33^{\mathrm{d}}$ & $101.7^{\mathrm{c}}$ & $15.67^{\mathrm{bc}}$ & $17.00^{\mathrm{b}}$ & $178.0^{\mathrm{c}}$ & $198.7^{\mathrm{b}}$ \\
\hline & With & - & $80.67^{\mathrm{e}}$ & $81.33^{\mathrm{f}}$ & $14.33^{\mathrm{c}}$ & $13.33^{\text {ef }}$ & $104.0^{\mathrm{g}}$ & $103.3^{\mathrm{f}}$ \\
\hline & & + & $98.67^{\mathrm{c}}$ & $95.33^{d}$ & $16.33^{\mathrm{ab}}$ & $14.33^{\mathrm{de}}$ & $140.7^{\mathrm{d}}$ & $131.0^{\mathrm{d}}$ \\
\hline & Without & - & $80.67^{\mathrm{e}}$ & $82.00^{\mathrm{f}}$ & $14.33^{\mathrm{c}}$ & $16.00^{\mathrm{bc}}$ & $109.3^{\mathrm{f}}$ & $111.3^{\mathrm{e}}$ \\
\hline \multirow{3}{*}{ Biofertilization } & & + & $104.3^{\mathrm{b}}$ & $113.3^{\mathrm{b}}$ & $16.00^{\mathrm{ab}}$ & $18.67^{\mathrm{a}}$ & $211.0^{\mathrm{b}}$ & $150.3^{\mathrm{c}}$ \\
\hline & With & - & $118.3^{\mathrm{a}}$ & $86.00^{\mathrm{e}}$ & $14.33^{\mathrm{c}}$ & $15.00^{\mathrm{cd}}$ & $128.0^{\mathrm{e}}$ & $107.7^{\mathrm{ef}}$ \\
\hline & & + & $120.7^{\mathrm{a}}$ & $121.0^{\mathrm{a}}$ & $17.33^{\mathrm{a}}$ & $19.33^{\mathrm{a}}$ & $218.0^{\mathrm{a}}$ & $211.3^{\mathrm{a}}$ \\
\hline
\end{tabular}

*Values having the same alphabetical letter(s) did not significantly differ at the $\mathrm{p}>0.05$ level of significance, according to Duncan's multiple range test.

Table 7. Effect of integrated fertilization management on chemical constitutes of pea seeds.

\begin{tabular}{|c|c|c|c|c|c|c|c|c|c|c|c|c|}
\hline \multirow[b]{3}{*}{ Fertilization } & \multicolumn{2}{|c|}{ Treatments } & \multicolumn{2}{|c|}{$\mathrm{N}$} & \multicolumn{2}{|c|}{$\mathrm{P}$} & \multicolumn{2}{|c|}{ K } & \multicolumn{2}{|c|}{$\begin{array}{c}\text { Total } \\
\text { protein }\end{array}$} & \multicolumn{2}{|c|}{$\begin{array}{c}\text { Total } \\
\text { carbohydrates }\end{array}$} \\
\hline & \multicolumn{2}{|c|}{ Foliar application } & \multicolumn{10}{|c|}{$(\%)$} \\
\hline & $\begin{array}{l}\text { Micro- } \\
\text { elements }\end{array}$ & $\begin{array}{c}S . \\
\text { cerevi } \\
\text { siae }\end{array}$ & $1^{\text {st }}$ & $2^{\text {nd }}$ & $1^{\text {st }}$ & $2^{\text {nd }}$ & $1^{\text {st }}$ & $2^{\text {nd }}$ & $1^{\text {st }}$ & $2^{\text {nd }}$ & $1^{\text {st }}$ & $2^{\text {nd }}$ \\
\hline \multirow{5}{*}{ Chemical } & Without & - & $3.50^{\mathrm{bc}}$ & $3.30^{\mathrm{c}^{*}}$ & $0.343^{\mathrm{d}}$ & $0.373^{\mathrm{e}}$ & $0.79^{\mathrm{d}}$ & $0.76^{\mathrm{e}}$ & $20.2^{\mathrm{d}}$ & $20.6^{\mathrm{c}}$ & $41.7^{\mathrm{d}}$ & $43.0^{\mathrm{c}}$ \\
\hline & & + & $3.60^{\mathrm{bc}}$ & $3.53^{\mathrm{abc}}$ & $0.386^{\mathrm{b}}$ & $0.400^{\mathrm{cd}}$ & $1.05^{\mathrm{c}}$ & $0.89^{\mathrm{de}}$ & $21.3^{\mathrm{cd}}$ & $21.3^{\mathrm{bc}}$ & $43.3^{\mathrm{cd}}$ & $44.7^{\mathrm{bc}}$ \\
\hline & With & - & $3.36^{\mathrm{cd}}$ & $3.40^{\mathrm{bc}}$ & $0.373^{\text {bc }}$ & $0.390^{\mathrm{d}}$ & $0.51^{\mathrm{e}}$ & $0.74^{\mathrm{e}}$ & 21. $0^{\text {cd }}$ & $21.4^{\mathrm{bc}}$ & $42.9^{\text {cd }}$ & $45.1^{\mathrm{bc}}$ \\
\hline & & + & $3.5^{\mathrm{bcd}}$ & $3.56^{\mathrm{abc}}$ & $0.390^{\mathrm{b}}$ & $0.410^{\mathrm{c}}$ & $0.97^{\mathrm{c}}$ & $0.98^{\mathrm{cd}}$ & $22.1^{\mathrm{bcd}}$ & $22.1^{\mathrm{abc}}$ & $46.7^{\mathrm{a}}$ & $47.7^{\mathrm{a}}$ \\
\hline & Without & - & $3.30^{\mathrm{d}}$ & $3.43^{\mathrm{bc}}$ & $0.350^{\mathrm{cd}}$ & $0.403^{\text {cd }}$ & $0.94^{\mathrm{c}}$ & $1.09^{\mathrm{bc}}$ & $22.1^{\mathrm{bcd}}$ & $22.3^{\mathrm{abc}}$ & $42.9^{\text {cd }}$ & $44.2^{\mathrm{bc}}$ \\
\hline \multirow{3}{*}{ Bio. } & & + & $3.40^{\text {cd }}$ & $3.83^{\mathrm{a}}$ & $0.386^{\mathrm{b}}$ & $0.410^{\mathrm{c}}$ & $1.24^{\mathrm{b}}$ & $1.42^{\mathrm{a}}$ & $22.5^{\mathrm{bc}}$ & $23.1^{\mathrm{ab}}$ & $45.4^{\mathrm{ab}}$ & $46.2^{\mathrm{ab}}$ \\
\hline & With & - & $3.66^{\mathrm{ab}}$ & $3.70^{\mathrm{ab}}$ & $0.423^{\mathrm{a}}$ & $0.430^{\mathrm{b}}$ & $0.99^{\mathrm{c}}$ & $1.21^{\mathrm{b}}$ & $22.9^{\mathrm{ab}}$ & $23.8^{\mathrm{a}}$ & $44.1^{\mathrm{bc}}$ & $46.2^{\mathrm{ab}}$ \\
\hline & & + & $3.90^{\mathrm{a}}$ & $3.80^{\mathrm{a}}$ & $0.430^{\mathrm{a}}$ & $0.446^{\mathrm{a}}$ & $1.73^{\mathrm{a}}$ & $1.43^{\mathrm{a}}$ & $24.4^{\mathrm{a}}$ & $23.9^{\mathrm{a}}$ & $46.9^{\mathrm{a}}$ & $48.4^{\mathrm{a}}$ \\
\hline
\end{tabular}

*Values having the same alphabetical letter(s) did not significantly differ at the $p>0.05$ level of significance, according to Duncan's multiple range test.

\subsection{Effect of Integrated Fertilization Management on Chemical Constituents of Pea Seeds}

Results are presented in Table (7) indicated that the chemical constituents of pea seeds as a response of integrated fertilization management. Data showed that the highest values of all estimated parameters, i.e. N, P, K and total protein in pea seeds were observed in plants inoculated with biofertilizers in combination with foliar application (yeast extract and micronutrients). This trend of results was observed in the two growing seasons. In this respect, Mohamed [21] found that active dry yeast as a foliar application had a beneficial effect on chemical constituents of pea plants. Also, Kumar and Haripriya [17] reported that spraying of plants with $\mathrm{Zn}, \mathrm{Mn}$ or Fe increased plant content of N, P, K, Zn, Mn and Fe.

On the other hand, there were no significant differences between total carbohydrate values in plants treated with either biofertilizers or chemical fertilization in combination with yeast extract and micronutrients. This may be due to the synergistic effect between all applied microorganisms as Patale and Shinde [25] opinion, since they found that mycorrhizal infection increase total proteins and content of nitrogen, phosphorus and potassium in AM fungi treated seedlings as compared to non-mycorrhizal seedlings (control). Also the lowest value of phosphorus and potassium in pea seeds was observed in plants fertilized with NPK only and NPK in combination with micronutrients, respectively. 
Table 8. Effect of integrated fertilization management on yield and yield components of pea.

\begin{tabular}{|c|c|c|c|c|c|c|c|c|c|c|c|c|}
\hline \multirow[b]{3}{*}{ Fertilization } & \multicolumn{2}{|l|}{ Treatment } & \multicolumn{2}{|c|}{$\begin{array}{l}\text { Number of } \\
\text { pods/plant }\end{array}$} & \multicolumn{2}{|c|}{$\begin{array}{l}\text { Weight of pod } \\
(\mathrm{g})\end{array}$} & \multicolumn{2}{|c|}{$\begin{array}{c}\text { Number of } \\
\text { seed/pod }\end{array}$} & \multicolumn{2}{|c|}{$\begin{array}{c}\text { Dry weight of } 100 \\
\text { seed }(\mathrm{g})\end{array}$} & \multicolumn{2}{|c|}{ Yield (ton/fad.) } \\
\hline & \multicolumn{12}{|c|}{ Foliar application } \\
\hline & $\begin{array}{c}\text { Micro- } \\
\text { elements }\end{array}$ & $\begin{array}{c}S . \\
\text { cerevisiae }\end{array}$ & $1^{\text {st }}$ & $2^{\text {nd }}$ & $1^{\text {st }}$ & $2^{\text {nd }}$ & $1^{\text {st }}$ & $2^{\text {nd }}$ & $1^{\mathrm{st}}$ & $2^{\text {nd }}$ & $1^{\text {st }}$ & $2^{\text {nd }}$ \\
\hline \multirow{4}{*}{ Chemical } & Without & - & $25.33^{\mathrm{d}^{*}}$ & $20.00^{\mathrm{e}}$ & $5.33^{\mathrm{d}}$ & $5.81^{\mathrm{e}}$ & $7.6^{\mathrm{d}}$ & $7.3^{\mathrm{d}}$ & $11.00^{\mathrm{e}}$ & $11.33^{d}$ & $3.66^{\mathrm{b}}$ & $4.13^{\mathrm{e}}$ \\
\hline & & + & $35.33^{\mathrm{c}}$ & $36.67^{\mathrm{c}}$ & $5.66^{\mathrm{cd}}$ & $6.15^{\mathrm{d}}$ & $8.3^{\mathrm{cd}}$ & $8.0^{\mathrm{c}}$ & $13.00^{\mathrm{c}}$ & $14.00^{\mathrm{ab}}$ & $4.06^{\mathrm{a}}$ & $4.46^{\mathrm{b}}$ \\
\hline & With & - & $27.00^{\mathrm{d}}$ & $23.33^{\mathrm{e}}$ & $6.33^{\mathrm{b}}$ & $7.03^{\mathrm{b}}$ & $7.6^{\mathrm{d}}$ & $7.6^{\mathrm{d}}$ & $12.00^{\mathrm{d}}$ & $12.67^{\mathrm{cd}}$ & $3.76^{\mathrm{b}}$ & $4.16^{\mathrm{de}}$ \\
\hline & & + & $38.67^{b}$ & $56.33^{\mathrm{b}}$ & $7.33^{\mathrm{a}}$ & $7.29^{\mathrm{ab}}$ & $9.0^{\mathrm{bc}}$ & $8.6^{\mathrm{b}}$ & $14.00^{\mathrm{b}}$ & $13.33^{\mathrm{bc}}$ & $4.13^{\mathrm{a}}$ & $4.53^{\mathrm{ab}}$ \\
\hline \multirow{4}{*}{ Bio. } & \multirow[t]{2}{*}{ Without } & - & $40.33^{b}$ & $31.33^{\mathrm{d}}$ & $6.33^{\mathrm{b}}$ & $5.84^{\mathrm{e}}$ & $8.0^{\mathrm{d}}$ & $7.6^{\mathrm{d}}$ & $12.00^{\mathrm{d}}$ & $11.67^{\mathrm{ef}}$ & $3.66^{\mathrm{b}}$ & $4.23^{\mathrm{cd}}$ \\
\hline & & + & $49.00^{\mathrm{a}}$ & $56.0^{\mathrm{b}}$ & $7.00^{\mathrm{a}}$ & $7.41^{\mathrm{a}}$ & $9.3^{\mathrm{ab}}$ & $9.0^{\mathrm{a}}$ & $11.00^{\mathrm{e}}$ & $12.00^{\mathrm{def}}$ & $4.10^{\mathrm{a}}$ & $4.53^{\mathrm{ab}}$ \\
\hline & \multirow[t]{2}{*}{ With } & - & $39.67^{b}$ & $33.67^{\mathrm{cd}}$ & $6.00^{\mathrm{bc}}$ & $6.48^{\mathrm{c}}$ & $9.0^{\mathrm{bc}}$ & $8.0^{\mathrm{c}}$ & $13.00^{\mathrm{c}}$ & $12.33^{\mathrm{de}}$ & $3.73^{\mathrm{b}}$ & $4.26^{\mathrm{c}}$ \\
\hline & & + & $52.00^{\mathrm{a}}$ & $63.33^{\mathrm{a}}$ & $7.00^{\mathrm{a}}$ & $7.58^{\mathrm{a}}$ & $10.0^{\mathrm{a}}$ & $9.3^{\mathrm{a}}$ & $15.00^{\mathrm{a}}$ & $14.67^{\mathrm{a}}$ & $4.20^{\mathrm{a}}$ & $4.56^{\mathrm{a}}$ \\
\hline
\end{tabular}

*Values having the same alphabetical letter(s) did not significantly differ at the $\mathrm{p}>0.05$ level of significance, according to Duncan's multiple range test.

\subsection{Effect of Integrated Fertilization Management on Yield and Its Components of Pea}

Data in Table (8) shows the all estimated pea yield parameters, i.e. number of the pods/plant, weight of pod $(\mathrm{g})$, number of seed/pod and dry weight of 100 seed $(\mathrm{g})$ were significantly affected by all applied treatments in this study during the two growing seasons. Also, there were no significant differences between the number of pods/plant and number of seed/pod in plants inoculated with biofertilizers with yeast extract in presence or absence of micronutrients in the first season. In addition, this trend of results was observed in weight of pod ( $\mathrm{g}$ ) in two growing seasons.

These results are in agreement with Badr et al. [6] who indicated that inoculated pea significantly surpassed on un-inoculated ones in a number of pods/plant, seed yield/plant, 100-seed weight and seed yield/fed as well as number of seed/pod, pods weight/plant. Plants fertilized with NPK in combination without any foliar applications gave the lowest records of all estimated pea yield parameters. Whereas, plants fertilized with NPK in combination with yeast extract and micronutrients gave higher pod weight (g). These results are in harmony with Naeem [23] who reported that application of nitrogen and phosphorus produced maximum length of the pod and maximum number of pods per plant. Also, Gupta et al. [13] observed that phosphorus application increased seed yield and yield parameters such as pod length, number of grains per pod and pod weight.

\section{Conclusions}

Obtained results indicated that growth performance and yield of pea were significantly affected by application of biofertilizers in combination with foliar spraying with micronutrients and Saccharomyces extracts. In addition, results proved that using of biofertilization reduced the amount used of chemical fertilizer by $50 \%$. Also, spraying with yeast extract can be an alternative method to spray with synthetic industrial growth hormones to avoid their adverse effects on human health.

\section{REFERENCES}

[1] A.O.A.C., Association of Official Agriculture Chemists 2005. Official methods of analysis of association of official analytical chemists. $17^{\text {th }}$ ed. Washington, DC, USA

[2] A.P.H.A., American Public Health Association 1992. Standard Methods for the Examination of Water and Wastewater. Washington, DC, U.S.A.

[3] Abdel-Rahim, E.A.; Shallan, M.A. and El-Scheik, A.M. 1988. Biochemical studies on production of new thermophilic yeast alkaline proteases applied for the purposes of laundry detergents industry. J. Agric. Sci. Mansoura Univ., 21(5):1971-1985.

[4] Andrzejewska, J. 2002. Yield and agronomic conditions of nodulation in different pea varieties (Pisum sativum L.). Rozp. Hab., 105. Bydgoszcz. pp:91.

[5] Anne-Sophie, V.; Christophe, S.; Nathalie, G.M. and Bertrand, N. 2002. Quantitative effects of soil nitrate, growth potential and phenology on symbiotic nitrogen fixation of pea (Pisum sativum L.). Plant Soil, 243:31-42.

[6] Badr, Elham, A.; Bahr, Amany, A.; Amin, Gehan, A. and Wali, A.M. 2014. Response of sweet lupin (Lupinus albus L.) to spraying with molybdenum, bio and nitrogen fertilizer on seed yield and quality. Middle East J. Agric. Res., 3(2):363-367.

[7] Dewis, G. and Freitas, F. 1970. Physical and chemical methods of soil and water analysis. FAO, Bull., No (10).

[8] Drobrikova, V. 1961. Factors influencing the determination 
of phosphatase in soil. Folia. Microbiol, 6:260.

[9] Dubois, M.; Gilles, K.A.; Hamilton, J.K.; Robers, P.A. and Smith, F. 1956. Colorimetric method for determination of sugar and related substances. Anal. Chem. 28(3):350-356.

[10] Duncan's, D.B. 1955. Multiple range and multiple F. test. Biometrics, 11:11- 24.

[11] El-Kramany, M.F.; Ahmed, M.K.; Bahr, A.A. and Kabesh, M.O. 2000. Utilization of bio-fertilizers in field crop production. Egypt J. Appl. Sci., 15(11):137-149.

[12] Grotz, N. and Guerinot, M.L. 2006. Molecular aspects of $\mathrm{Cu}$, $\mathrm{Fe}$ and $\mathrm{Zn}$ homeostasis in plants. Biochem. Biophys. Acta, 1763:595-608.

[13] Gupta, C.R.; Sengar, S.S. and Singh, J. 2000. Growth and yield of table pea (Pisum sativum L.) as influenced by levels of phosphorus and lime in acidic soil. Veg. Sci., 27(1):101-102.

[14] Hammad, S.A.R. 2008. Physiological and anatomical studies on drought tolerance of pea plants by application of some natural extracts. Ann. Agric. Sci., Ain Shams Univ., Cairo, Egypt 53(2):285-305.

[15] Helmy, M. 2013. Effect of magnettte, humic acid and biofertilizer application on growth, yield and quality of pea (Pisum sativum L.). Ph.D. Agric., Fac. Agric., Mansoura Univ., Egypt.

[16] Herron, P.R. and Wellington, M.H. 1990. New method for extraction of Streptomyces spores from soil and application to the study of lysogeny in sterile amended and non-sterile soil. Appl. Environ. Microbiol, 56(5):1406-1412.

[17] Kumar, S. and Haripriya, K. 2010. Effect of foliar application of iron and zinc on growth, flowering and yield on nerium (Nerium odorum L.). Plant Archives, 10(2):637-640.

[18] Loguerre, G. 2008. Plant phenology and genetic variability in root and nodule development strongly influence genetic structuring of Rhizobium leguminosarum biovar viciae populations nodulating pea. New Phytol, 179: 224-235

[19] Mahmoud, Asmaa, R.; EL-Desuki, M.; Abdel-Mouty, Mona, M. and Ali, Aisha, H. 2013. Effect of compost levels and yeast extract application on the pea plant growth, pod yield and quality. J. App. Sci. Res., 9(1):149-155.

[20] Mishra, A.; Prasad, K. and Rai, G. 2010. Effect of bio-fertilizer inoculations on growth and yield of dwarf field pea (Pisum sativum L.) in conjunction with different doses of chemical fertilizers. J. Agro., 9:163-168.

[21] Mohamed, S.E. 2005. Photochemical studies on common bean (Phaseolus vulgaris, L.) plants as affected by foliar fertilizer and active dry yeast under sandy soil conditions. Egypt J. Appl. Sci., 20(5):539-559.

[22] Musandu, A.A.O. and Giller, K.E. 1994. Effect of vesicular-arbuscular mycorrhiza on kubzu (Pueraria phaseoloides) growth in phosphate fixing Kenya soils. African crops Sci. J., 2(3):285-290.

[23] Naeem, A. 2003. Effect of different levels of nitrogen and phosphorus on green pods and seed yield of pea. M.Sc. Thesis, Inst. of Hort. Sci., Uni. Agri., Faisalabad, Paksitan.

[24] Page, A.L.; Miller, R.H. and Kenney, D.R. 1982. Methods of soil analysis: chemical and microbiological properties, Part 2, pp: 39-41. SSSP, Inc., Madison, Wisconsin, USA.

[25] Patale, S.W. and Shinde, B.P. 2014. Effect of water and salt stress on Bt-cotton inoculated with AM fungi. Ind. J. Res. Studies in Pure and Appl. Sci., 2(1\&2):50-56.

[26] Sarkar, D.; Mandal, B. and Kundu, M.C. 2007. Increasing use efficiency of boron fertilizers by rescheduling the time and methods of application for crops in India. Plant Soil, 301:77-85.

[27] Shumin, L.; Long, L. and Zhang, F. 2004. Enhancing phosphorus and nitrogen uptake of faba bean by inoculating arbuscular mycorrhizal fungus and Rhizobium leguminosarum. J. China Agric. Univ., 9(1):11-15.

[28] Silvester, W.B. 1983. Analysis of nitrogen fixation in forest ecosystems. In: Biological Nitrogen Fixation in Forest Ecosystems. Foundations and Applications, Gordon, J.M. and Wheeler, C.T. (Eds.). M artinus Nijhoff, The Hague, p: $173-212$.

[29] Snedecor, G.W. and Cochran, W.G. 1989. Statistical methods. $8^{\text {th }}$ ed. Iowa State Univ. Press, Ames Iowa, USA.

[30] Somasegaran, P. and Hoben, H. I. 1985. Methods in legume. Rhizobium Technology University of Hawaii NIFTAL project and MIRCEN-USAID.

[31] Subba-Rao, N.S. 2002. Soil microbiology $\left(4^{\text {th }}\right.$ ed. soil microorganisms and plant growth), Oxford and IBH publication company, New Delhi, p: 211-228.

[32] Sultana, N.; Ikeda, T. and Kashem, M.A. 2001. Effect of foliar spray of nutrient solutions on photosynthesis, dry matter accumulation and yield in seawater-stressed rice. J. Environ. Exp. Bot., 46(20):129-140.

[33] Tagore, G.S.; Namdeo, S.L.; Sharma, S.K. and Kumar, N. 2013. Effect of Rhizobium and phosphate solubilizing bacterial inoculants on symbiotic traits, nodule legheamoglobin and yield of chickpea genotypes. Inter. J. Agro. 58:16-27.

[34] Vincent, J.M. 1970. A manual for the practical study of root nodule bacteria. Blackwell Sci. Pub., Oxford, UK.

[35] Xiurong, W.; Qiang, P.; Fengxian, C.; Xiaolong, Y. and Hong, L. 2011. Effects of co-inoculation with arbuscular mycorrhizal fungi and rhizobia on soybean growth as related to root architecture and availability of $\mathrm{N}$ and P. Mycorrhiza 21:173-181.

[36] Yosefi, K.; Galavi, M.; Ramrodi, M. and Mousavi, S.R. 2011. Effect of bio-phosphate and chemical phosphorus fertilizer accompanied with micronutrient foliar application on growth, yield and yield components of maize. Aus. J. Crop Sci., 5(2):175-180.

[37] Zaki, Nabila, M.; Hassanein, M.S. and Gamal El-Din, K.M. 2007. Growth and yield of some wheat cultivars irrigated with saline water in newly cultivated land as affected by biofertilization. J. Appl. Sci. Res., 3(10):1121-1126. 